\title{
De accountant en fraude
}

\section{Hoofdstuk 1: Inleiding}

\subsection{Probleemstelling}

Fraude is een probleem dat weliswaar heel oud is, maar dat in onze maatschappij nog springlevend blijkt te zijn. Voor voorbeelden van hedendaagse fraudes moge worden verwezen naar de fraudes die met een zekere regelmaat in de pers worden beschreven. Aan een fraudegeval vallen vele aspecten te onderkennen, bijvoorbeeld van menselijke maar ook van strafrechtelijke aard.

In dit artikel zal het fraudeprobleem worden benaderd vanuit de accountancy. Als probleemstelling is daarbij gekozen voor de vraag in hoeverre de accountant verantwoordelijk is voor het niet of niet tijdig op het spoor komen van fraudes bij de gecontroleerde huishouding.

Zoals uit het vervolg van dit artikel zal blijken, kan op deze vraag slechts een genuanceerd antwoord worden gegeven. Deze antwoorden zijn samengevat in de conclusies welke in hoofdstuk 4 zijn opgenomen.

\subsection{Naar een definitie van fraude}

Bij de afbakening van een probleemgebied kan een definitie een nuttige functie vervullen.

In de literatuur worden enkele definities van fraude gevonden. Een veel geciteerde definitie is de definitie van Brugge ${ }^{4}$, die fraude als volgt definieert:

'Fraude is het zichzelf dan wel anderen wederrechtelijk bevoordelen en wel met behulp van bedrieglijke middelen, door misbruik van het in dienstbetrekking geschonken vertrouwen'.

Frielink ${ }^{4}$ acht deze definitie enerzijds te beperkt 'omdat zij alleen de fraudeur in dienstbetrekking (en derhalve niet bijvoorbeeld de penningmeester van een vereniging) in de begripsbepaling betrekt'.

Anderzijds acht Frielink de term 'met behulp van bedrieglijke middelen' zo ruim, dat het meer omvat dan waar de accountant mee te maken heeft. Op grond van deze bezwaren verwerpt hij de definitie van Brugge en komt dan tot de volgende formulering:

'Onder fraude wordt verstaan het door een natuurlijk persoon zodanig manipuleren van gegevens dat onrechtmatige onttrekking van waarden aan een huishouding wordt vergemakkelijkt en/of haar ontdekking wordt bemoeilijkt'. 
Het aantrekkelijke van deze definitie is de introductie van een AO-achtig element, namelijk het manipuleren van gegevens en de erkenning van het feit dat ook een (nog) niet voltooide fraude wel degelijk een fraude is. Anderzijds rijst de vraag of fraude beperkt is tot het onttrekken van waarden. Zo signaleert Van 't Klooster' ${ }^{3}$ het geval waarin een afdelingschef tegen betaling een programmeur de verdeelsleutels in een computerprogramma, dat de algemene kosten toerekende, liet wijzigen.

Hoewel hier geen sprake is van het onttrekken van waarden, is hier onzes inziens wèl sprake van fraude. Derhalve is de definitie van Frielink op dit punt te eng geformuleerd.

Teneinde richting te geven aan dit woordenspel is het wellicht goed na te gaan hoe in de woordenboeken van Van Dale en Koenen het woord fraude wordt gedefinieerd. Beide geven in hun omschrijving voor fraude het woord bedrog. Derhalve is de term 'bedrieglijke middelen' uit de definitie van Brugge hier onzes inziens zeer op zijn plaats.

Het is geen nadeel hier een ruim begrip te introduceren, aangezien van te voren nooit kan worden afgeperkt met welke fraudemiddelen de accountant zal worden geconfronteerd.

De hiervoor geciteerde woordenboeken geven aan, welke betekenis in de maatschappij aan bepaalde woorden wordt toegekend. Gesteld zou kunnen worden dat hierin de opvatting van het zogenaamde maatschappelijk verkeer over het begrip fraude kan worden terug gevonden.

Uitgaande van de definitie van Frielink en rekening houdend met de term 'bedrieglijke middelen' zijn wij tot de volgende definitie van fraude gekomen:

'Fraude is het door een natuurlijk persoon met bedrieglijke middelen manipuleren van gegevens en/of organisaties zodat een onrechtmatige bevoordeling van zichzelf of anderen wordt vergemakkelijkt en/of haar ontdekking wordt bemoeilijkt'.

Van deze definitie verdienen 2 elementen nog nadere aandacht.

Teneerste de passage 'manipuleren van gegevens en/of organisaties'.

Onzes inziens is het fraudeprobleem in belangrijke mate een probleem van interne controle. Een goed opgezette en goed werkende interne controle vormt in deze gedachtengang een barrière tegen mogelijke fraudes.

Anderzijds zullen fraudeurs trachten door het veranderen van gegevens en/ of het doorbreken van de opzet van de organisatie deze interne controle buiten spel te zetten. In $\S 2.3$ zal blijken dat dit bijvoorbeeld kan geschieden middels samenspanning.

Een andere mogelijkheid is dat het systeem van interne controle wordt doorbroken door de leiding van de huishouding. In hoofdstuk 3 zal aan management fraude aparte aandacht worden besteed, omdat het feit dat de leiding van de huishouding in staat is de opzet van de organisatie te doorbreken dan wel te omzeilen voor de accountant belangrijke consequenties heeft.

Ten tweede de term 'bevoordeling'. Frielink hanteert in zijn definitie de term 'onttrekking van waarden'. Zoals in $\S 3.2$ aan de orde zal komen wordt bij het begrip fraude inderdaad veelal gedacht aan het onttrekken van waarden. Deze vorm van fraude kan tot op zekere hoogte worden bemoeilijkt 
met behulp van een goede interne controle.

Daarnaast is een vorm van fraude mogelijk die als het geven van een valse voorstelling van zaken kan worden getypeerd. Hiermee wordt dan het terrein van de management-fraude betreden, waar de werking van de interne controle zeer zwak dan wel afwezig kan zijn.

Teneinde beide vormen van fraude in de beschouwing te kunnen betrekken is gekozen voor de ruimere term 'bevoordeling'.

De vraag zou kunnen rijzen of een aparte fraude-categorie wordt gevormd door die fraudes waarbij een computer in het spel is.

Volgens Van 't Klooster ${ }^{3}$ zijn deze zogenaamde computerfraudes in wezen gelijk aan 'gewone fraudes'. Zijns inziens is het de mens die fraudeert waarbij de computer als technisch hulpmiddel wordt gebruikt, dan wel de organisatie rond de computer wordt doorbroken.

Onzes inziens is ook de computerfraude in de grond van de zaak een probleem van interne controle. Bij computerfraude zal de fraudeur trachten de computer als hulpmiddel te gebruiken bij de uitvoering van zijn fraude. Teneinde dit te bereiken dient hij de barrière van de interne controle te doorbreken.

Bij de nadere uitwerking van zijn standpunt toont Van 't Klooster aan dat het gebruik van de computer in bepaalde opzichten de mogelijkheden tot fraude vergroot, maar in andere opzichten die mogelijkheden juist weer verkleint.

Deze aspecten vallen echter buiten het bestek van dit artikel.

\section{Hoofdstuk 2: Het fraudeprobleem benaderd als intern controle probleem}

\subsection{De vertrouwensleer van Limperg}

$\mathrm{Na}$ aldus het verschijnsel fraude te hebben gedefinieerd, stellen wij de vraag welke de positie van de accountant is ten opzichte van fraude. Met de term accountant wordt in dit artikel bedoeld de accountant die is belast met onderzoek naar de getrouwheid van een verantwoording. De term accountant omvat in deze visie dus zowel de interne als de externe accountant.

Onzes inziens kan de positie van de accountant ten opzichte van fraude worden weergegeven als de volgende driehoeksverhouding

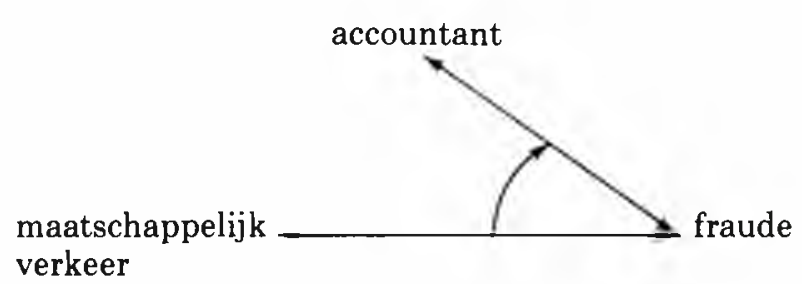

Volgens Limperg dient de accountant zijn werkzaamheden zo te verrichten dat hij de verwachtingen die hij bij de verstandige leek opwekt niet beschaamt; omgekeerd mag de accountant geen grotere verwachtingen opwekken dan door de verrichte arbeid worden gerechtvaardigd. De positie van de accountant ten opzichte van fraude wordt dus bepaald door de 
opvatting van het maatschappelijk verkeer ten aanzien van fraude. Het verschijnsel fraude kan zich niet zelfstandig manifesteren maar altijd als fraude bij een bepaalde huishouding. In de hiervoor geschetste driehoeksverhouding wordt dan de basis gevormd door de relatie maatschappelijk verkeer-fraude (bij een huishouding) en vormt de relatie accountant-fraude (bij die huishouding) slechts een afgeleide van de eerste.

De omschrijving van het begrip fraude door het maatschappelijk verkeer is in de voorgaande paragraaf al leidraad geweest voor onze definitie van het begrip fraude. Voor de accountant is van belang welke verwachtingen het maatschappelijk verkeer koestert ten aanzien van mogelijke fraudes bij een huishouding waar een accountant fungeert. Indien dit gerechtvaardigde verwachtingen zijn, dient de accountant deze niet te beschamen. Indien deze niet gerechtvaardigd c.q. niet rationeel zijn, dient het beroep hier ondubbelzinnig duidelijkheid over te verschaffen.

Wanneer in het beroep wordt gesproken over de positie van de accountant wordt telkenmale het maatschappelijk verkeer ten tonele gevoerd.

De vraag zou kunnen rijzen wat men zich daarbij moet voorstellen.

Want ondanks de wat vage inhoud van dit begrip, zou de accountant een vertrouwensrelatie met dat maatschappelijk verkeer hebben.

De meeste auteurs concretiseren het begrip door het geven van reeksen voorbeelden van groepen die in elk geval tot dat maatschappelijk verkeer moeten worden gerekend. Hierbij worden doorgaans de aandeelhouders, de spaarders, de beleggers, de crediteuren, de pers, SOBI, de bankiers, de werknemers, de afnemers en de overheid genoemd.

Deze categorieën overziend, kan onzes inziens niet worden volgehouden, dat de accountant met allen een vertrouwensrelatie heeft. Daar komt nog bij dat eventuele interesse in de loop van de tijd kan toe- of afnemen.

De belangstelling van werknemers kan bijvoorbeeld jarenlang latent aanwezig zijn geweest. Indien geruchten de ronde doen dat de continuïteit van de huishouding in gevaar is, kan deze belangstelling zeer aktief worden. De vraag is dan of men de gewenste informatie via het jaarverslag, inclusief accountantsverklaring, zal verkrijgen. Gewoonlijk zal men vertrouwen op de informatievoorziening en belangenbehartiging door bijvoorbeeld de overheid en de vakbeweging.

Het is de verdienste van Van der Hooft ${ }^{2}$ geweest er op te wijzen dat de lijn van het vertrouwen dikwijls loopt via intermediaire instanties.

Hij onderscheidt een bovenlaag van informerende, toezichthoudende, belangenbehartigende en zelfs vertegenwoordigende instellingen en een onderlaag van uiteindelijke belanghebbenden.

De eerste categorie fungeert als een 'vertrouwens intermedium' voor de tweede categorie.

Dat verklaart ook waarom de functie en de betekenis van het optreden van een accountant bij het grote publiek niet leven.

De eerstgenoemden baseren hun oordeel wèl op de verantwoordingen van de leiding van de huishouding, inclusief de accountantsverklaring. Tussen deze categorie en de accountant zijn kontakten aanwijsbaar, bijvoorbeeld middels de Raad voor de Jaarverslaggeving. 
Concluderend kan worden gesteld, dat het maatschappelijk verkeer ten opzichte van de accountant een gelaagde structuur vertoont.

Wanneer in dit artikel over het maatschappelijk verkeer wordt gesproken, wordt gedoeld op de bovenlaag, die dan op zijn beurt als intermediair voor de onderlaag fungeert.

Ten aanzien van de verwachtingen van deze bovenlaag van het maatschappelijk verkeer is ons slechts een Amerikaanse enquête bekend. Van Schie ${ }^{9}$ beschrijft een in 1974 in de Verenigde Staten gehouden opiniepeiling waaruit bleek, dat $66 \%$ van de ondervraagde aandeelhouders en $68 \%$ van de ondervraagde vertegenwoordigers van de financiële pers van mening waren, dat het ontdekken van fraude het belangrijkste doel was van een accountantscontrole. Daarentegen was $94 \%$ van de ondervraagde accountants het met deze stelling niet eens ( $6 \%$ voelde wel wat voor deze stelling).

Onzes inziens valt op deze stelling wel wat af te dingen. Door de ondernemingsleiding wordt een verantwoording afgelegd. Door het maatschappelijk verkeer wordt een deskundig en onafhankelijk oordeel gevraagd over het beeld dat deze verantwoording oproept.

Het onderzoek van de accountant is gericht op het geven van zekerheid, namelijk het bevestigen dat hetgeen wordt gepresenteerd juist is en niet op het zoeken naar fouten, dus zeker niet gericht op het ontdekken van fraudes. Dat bij de controle fraudes aan het licht kunnen komen is als een 'bijprodukt' aan te merken, maar zeker niet als hoofdzaak. Dat is dus iets heel anders dan voornoemde ondervraagden als mening te kennen gaven.

De primaire verantwoordelijkheid voor het voorkomen dan wel ontdekken van een fraude ligt bij het bestuur van de gecontroleerde onderneming of instelling, dat de verantwoording aflegt en niet bij de accountant. Hoewel het de schijn heeft, is hiermee de kous voor de accountant niet af. Voor de accountant blijven er namelijk nog 2 vraagstukken over.

Ten eerste: hoever reikt zijn verantwoordelijkheid voor de administratieve en interne organisatie met de daarin opgenomen maatregelen van interne controle?

Ten tweede: hoe is zijn positie ten opzichte van een fraude die het beeld van een jaarrekening aantast, indien hij daarbij een goedkeurende verklaring heeft afgegeven?

Op deze 2 vraagstukken zal afzonderlijk worden ingegaan.

Terzijde zij opgemerkt, dat wat onder het beeld van een jaarrekening moet worden verstaan binnen het beroep nog niet is uitgekristalliseerd.

Wel kunnen aan de ontwerp-Richtlijnen en Boek 2 BW enige minimum vereisten voor wat betreft de te verstrekken informatie worden ontleend. Gesteld zou kunnen worden, dat hiermee de grens is aangegeven waar boven het beeld van de jaarrekening in elk geval wordt beïnvloed.

\subsection{De verantwoordelijkheid ex ante}

De primaire verantwoordelijkheid voor de administratieve en interne organisatie met de daarin opgenomen maatregelen van interne controle berust bij de leiding van de huishouding. Voor wat betreft de verantwoordelijkheid van de accountant op dit punt merkt Niekamp ${ }^{6}$ op, dat in het Ontwerp ter discussie nummer $1^{8}$ uit 1976 de mede-verantwoordelijkheid van de ac- 
countant voor de kwaliteit van de administratie wordt ontkend, althans niet expliciet erkend. Anderzijds geeft Niekamp aan dat de accountant 'in het kader van de toepassing van moderne controletechnieken, waarbij van de kwaliteit van de administratieve organisatie wordt uitgegaan, althans een afgeleide verantwoordelijkheid met betrekking tot de interne en de administratieve organisatie draagt'.

Frielink ${ }^{4}$ gaat zelfs zover, dat hij stelt dat, indien een goedkeurende verklaring wordt gegeven, het interne informatiesysteem voor wat betreft de interne controle niet-inadequaat is. Zijns inziens mag het maatschappelijk verkeer uit het feit dat bij de jaarrekening een goedkeurende verklaring is afgegeven, afleiden dat het informatiesysteem binnen de huishouding in de gegeven omstandigheden aan de eraan te stellen eisen voldoet.

Deze opvatting van Frielink heeft onzes inziens (te) verstrekkende consequenties.

Hoewel deze opvatting is gebaseerd op (veronderstelde) verwachtingen van het maatschappelijk verkeer, is dit door het beroep niet aanvaard omdat het (te) verstrekkende consequenties heeft.

Uit de praktijk is bekend, dat de leiding van de huishouding verwacht dat de accountant tenminste signaleert als er leemten in de interne en administratieve organisatie aanwezig zijn. Deze signaleringsfunctie zal tot meer gedetailleerde adviezen leiden naarmate de accountant langer bij dezelfde huishouding fungeert, maar tot een medeverantwoordelijkheid leidt dit niet.

Met andere woorden: het maatschappelijk verkeer (en de leiding van de huishouding) verwachten in elk geval, dat de accountant zich bezig houdt met fraude-preventie. Mijns inziens betreft het hier rationele verwachtingen en de accountant kan en moet in elk geval hierin voorzien. Dit zou kunnen worden getypeerd als de verantwoordelijkheid ex ante.

\subsection{De verantwoordelijkheid ex post}

Het tweede probleem wordt gevormd door het geval de accountant een goedkeurende verklaring bij de jaarrekening heeft afgegeven, waarna blijkt, dat zich een fraude heeft voorgedaan. De vraag is dan in hoeverre de accountant hiervoor verantwoordelijkheid draagt. Deze verantwoordelijkheid wordt wel getypeerd als de verantwoordelijkheid ex post.

Het eerste aanknopingspunt voor de beantwoording wordt gevonden in de door het bestuur van het Nivra aanbevolen tekst voor de goedkeurende verklaring. Daarin wordt gesproken van een getrouw beeld. De accountant verklaart dus dat het beeld dat de jaarrekening bij de lezer oproept juist is. Heel nadrukkelijk dekt de verklaring niet de laatste cent. Hieruit volgt dat fraudes die het beeld van de jaarrekening niet aantasten aan de verklaring geen afbreuk doen. Fraudes die het beeld van de jaarrekening niet aantasten vallen onzes inziens niet onder de verantwoordelijkheid ex post, mits de controlewerkzaamheden goed zijn uitgevoerd. Indien achteraf blijkt, dat fraude is gepleegd die het beeld van de jaarrekening met een goedkeurende verklaring aantast, zou men geneigd zijn de accountant verantwoordelijk te stellen omdat hij heeft verklaard, dat het beeld getrouw is en dat blijkt niet zo te zijn. 
Op de strekking van het begrip verantwoordelijkheid wordt hier niet nader ingegaan.

De commissie van advies inzake beroepsaangelegenheden behandelt in haar rapport van $1961^{4}$ dit probleem ook, maar de commissie acht de accountant dan niet in alle gevallen verantwoordelijk.

De commissie maakt namelijk een uitzondering voor de fraudes die niet door controle van de administratie aan het licht kunnen worden gebracht. Hiervoor zou dan het zogenaamde axiomatisch voorbehoud gelden. Voorts wenste men een uitzondering te maken voor de gevallen waar technische kennis een grote rol speelt. Gedoeld wordt dan op kennis die verder reikt dan die van de geïnteresseerde leek. Van $\mathrm{Schie}^{9}$ is van mening, dat de accountant hier minder onmachtig is dan het schijnt. Als oplossingen wijst hij op specialisatie naar bedrijfstak binnen een accountantskantoor en/of het inroepen van de hulp van externe experts.

Voor wat de eerste uitzondering betreft zij het volgende opgemerkt.

Indien blijkt dat de accountant, gemeten naar de huidige beroepsopvattingen, zijn controlewerkzaamheden niet goed heeft uitgevoerd en daardoor een fraude over het hoofd heeft gezien, die hij bij een goede uitvoering van het werk had kunnen ontdekken, dan treft deze accountant daarvoor blaam. Anderzijds is het denkbaar dat er fraudes bestaan, die door de accountant eenvoudigweg niet kunnen worden geconstateerd, ondanks de vaktechnisch juist opgezette en uitgevoerde controle. $Z o$ is het mogelijk dat door samenspanning de accountant om de tuin is geleid. Voorts is denkbaar dat het stelsel van interne controle door de leiding is doorbroken om frauduleuze handelingen van de leiding te verdoezelen.

Voor de zogenaamde management-fraude wordt verwezen naar hoofdstuk 3.

Voor wat betreft de samenspanning in het algemeen kan onzes inziens worden gesteld, dat het mogelijk is dat hierdoor een goed systeem van interne- en accountantscontrole wordt doorbroken. Gesteld zou kunnen worden dat tegen samenspanning, mits met de nodige perfectie opgezet en uitgevoerd, geen accountants-kruid is gewassen.

Voor dit aspect zou dan een axiomatisch voorbehoud gelden.

In de praktijk rijst voor de accountant de vraag, wanneer er sprake is van een vaktechnisch juist opgezette en uitgevoerde controle.

Het controleprogramma zal in elk geval een beoordeling van de opzet en de werking van de interne controle omvatten. Hierbij is het onderscheid in vervangbare en onvervangbare interne controle van belang.

Over de werking van de vervangbare interne controle is achteraf een gekwantificeerd oordeel mogelijk. Over de werking van de onvervangbare interne controle echter niet. Op grond hiervan zou gesteld kunnen worden, dat de accountant eerder blaam treft voor feilen in de werking in de vervangbare, dan in de werking van de onvervangbare interne controle.

Anderzijds dient bij de controle een zo goed mogelijk oordeel te worden gevormd over de werking van de onvervangbare interne controle.

Bij de bepaling van de omvang van de werkzaamheden teneinde te komen tot dat oordeel, zal de fraudegevoeligheid van een organisatie een rol spelen. 
Bij deze afweging mag het economisch motief niet uit het oog worden verloren.

Een behandeling van dit keuzeprobleem valt echter buiten het bestek van dit artikel.

Terzijde zij, voor wat het fraude aspect betreft, nog opgemerkt dat de accountant ervan mag uitgaan dat van een goede accountantscontrole al een zekere fraude-preventieve werking uitgaat.

\section{Hoofdstuk 3: Management-fraude}

\subsection{Het begrip management-fraude}

In het voorgaande is er impliciet van uitgegaan dat fraude wordt gepleegd door het (lagere) personeel. In dit hoofdstuk wordt aandacht besteed aan fraude gepleegd door het hogere personeel, wat wel wordt aangeduid met de term management-fraude. De reden voor de aparte behandeling van de management-fraude is, dat hier voor de accountant onzes inziens enkele bijzondere vraagstukken aan zijn verbonden, bijvoorbeeld omdat het optreden van het management deels buiten de werkingssfeer van de interne controle valt.

In het kader van de management-fraude zal aan de volgende vragen nader aandacht worden besteed:

1. Is er verschil in aard tussen management-fraude en fraude van het lagere personeel?

2. Is de hiërarchische opbouw van de organisatie van belang?

3. Is er in geval van management-fraude verschil in positie tussen de interne en de externe accountant?

Op deze 3 aspecten zal achtereenvolgens worden ingegaan.

\subsection{Verschil in aard van de fraude}

Bij het begrip fraude gaan de gedachten al snel uit naar het onttrekken van waarden aan de huishouding. Onzes inziens zal het bij fraude van het lagere personeel inderdaad veelal gaan om het onttrekken van waarden, hetgeen kan worden aangeduid met de term directe bevoordeling.

Een andere vorm van fraude zou kunnen worden getypeerd als het geven van een valse voorstelling van zaken. Sommigen menen dat daarmee exclusief het terrein van de management-fraude wordt betreden. Voortvloeiend hieruit definieert Van $\mathrm{Schie}^{9}$ management-fraude als: 'handelingen of nalatigheden van de leiding van de onderneming, waardoor het beeld van de jaarrekening opzettelijk misleidend wordt beïnvloed en wel ten nadele van de belanghebbenden bij deze jaarrekening'.

Deze definitie is gebaseerd op een bepaalde functie van de jaarrekening. Met de jaarrekening legt de ondernemingsleiding verantwoording af tegenover de kapitaalverschaffers over het gevoerde beleid. In dat kader kan het management er belang bij hebben een valse voorstelling van zaken te geven. Te denken valt hierbij aan een tendens de ondernemingspositie rooskleuriger voor te stellen dan zij in feite is, waardoor bepaalde personen hun positie binnen de onderneming kunnen verbeteren, dan wel hun inkomen 
verhogen of hun aandelenbezit in waarde kunnen doen stijgen.

Hierbij is dan sprake van een indirecte bevoordeling.

Van Schie gaat in zijn definitie echter voorbij aan de mogelijkheid dat het management er op uit kan zijn zichzelf te verrijken door het onttrekken van waarden. Vanuit deze visie somt hij een aantal controlemiddelen op en komt dan tot de conclusie dat management-fraude voor de accountant niet anders is dan fraude op een lager niveau.

Voor wat betreft het aspect van het geven van een valse voorstelling van zaken, kan het betoog van Van Schie worden gevolgd.

Dat betekent, dat de accountant, indien hij een goedkeurende verklaring bij de jaarrekening heeft afgegeven, verantwoordelijk is indien de leiding van de huishouding het beeld van de jaarrekening misleidend heeft beïnvloed. Slechts in zeer uitzonderlijke situaties zal een beroep op het axiomatisch voorbehoud mogelijk zijn.

Wellicht moet de in het voorgaande geciteerde Amerikaanse enquête zo worden geïnterpreteerd, dat men bedoelt te zeggen, dat dit een van de belangrijke onderdelen is waarop de accountant zijn controle dient te richten.

Uitgaande van het feit dat de ondernemingsleiding middels de jaarrekening verantwoording aflegt over het gevoerde beleid, impliceert een goedkeurende verklaring dat niet een te gunstig beeld van de gang van zaken wordt gegeven. Indien achteraf blijkt dat dat toch het geval is, is de accountant meestal mede verantwoordelijk.

Moeilijker wordt het echter voor de accountant, wanneer de leiding waarden aan de huishouding onttrekt, bijvoorbeeld door het buiten de boeken houden van transacties of het creëren van fictieve transacties. Er valt niet in te zien waarom management zich niet met dergelijke vormen van fraude zou bezighouden. Fraudes waarbij door het management waarden aan de huishouding worden onttrokken hebben voor de accountant een andere betekenis dan fraudes waarbij een valse voorstelling van zaken wordt gegeven, juist door de hoge plaats van het management in de organisatie.

Op deze speciale positie zal in de volgende paragraaf nader worden ingegaan.

\subsection{Het verschil in hiërarchisch niveau van de fraudeur}

Uit de praktijk is bekend dat degenen die het top-management vormen elkaars werk slechts voor wat de grote lijnen betreft beoordelen.

Derhalve is er binnen dit top-management nauwelijks sprake van een onderlinge controle.

Daarnaast is het management door zijn positie in staat maatregelen van interne controle te doorbreken, buiten werking te stellen of te omzeilen.

Een doorbreking van de interne controle kan overigens een geheel legitieme achtergrond hebben. In uitzonderlijke situaties is het denkbaar dat een beslissing hoog in de organisatie moet worden genomen en dat daarmee de opzet van de bestaande organisatie wordt doorbroken. Hierin schuilt echter de mogelijkheid dat de interne controle wordt doorbroken met minder oirbare bedoelingen.

De leiding zou dan moeten worden gecontroleerd door zijn ondergeschikten 
en denkbaar is, dat dat niet werkt omdat men bang is voor represailles. De ondergeschikte zou bijvoorbeeld kunnen menen door een kritische opstelling de kans te lopen zijn baan te verliezen en houdt dan uit angst zijn mond maar dicht. Deze situatie wordt door Frielink wel getypeerd als de omgekeerde hiërarchische verhoudingen (zie paragraaf 3.4).

Tegen deze doorbreking van de interne controle en tegen de gevolgen van de geringe onderlinge controle binnen de leiding is de accountantscontrole onzes inziens niet opgewassen, net zo min als de controle is opgewassen tegen bepaalde vormen van samenspanning (zie hoofdstuk 2).

De verantwoordelijkheid van de accountant voor management-fraude kan, analoog aan hoofdstuk 2 , als volgt worden samengevat.

Ook bij management-fraude vallen fraudes die het beeld van de jaarrekening niet aantasten buiten de verantwoordelijkheid ex post.

Ten aanzien van fraudes die het beeld van de jaarrekening wel aantasten draagt de accountant (mede-)verantwoordelijkheid, met echter de volgende kanttekening. Voor het niet ontdekken van bepaalde management-fraudes in de hiervoor geschetste 2 situaties geldt onzes inziens het axiomatisch voorbehoud, mits de controle uiteraard goed is opgezet en uitgevoerd volgens de huidige beroepsopvattingen.

\subsection{De positie van de interne accountant}

Als bij een huishouding een interne accountant is betrokken bij de controle van de jaarrekening kan de vraag rijzen welke zijn positie in geval van management-fraude is. Indien een fraude is gepleegd door de hoogste leiding van de huishouding en de interne accountant ontdekt dit, kan deze, net als overigens de externe accountant, hierdoor in ernstige verlegenheid worden gebracht. Frielink ${ }^{4}$ kenschetst deze situatie als de 'omgekeerde hiërarchische verhouding'. Dit betekent dat de ontdekker hiërarchisch ondergeschikt aan of lager in rang dan de fraudeur is. Op grond van deze omgekeerde hiërarchische verhouding acht Frielink de interne accountant niet verantwoordelijk voor de ontdekking van 'directie-fraude'.

Deze conclusie komt onzes inziens voort uit een visie waarbij sterk wordt getwijfeld aan de onafhankelijkheid van de interne accountant op grond van het feit dat deze accountant zelf deel uitmaakt van de organisatie van de gecontroleerde huishouding.

Onzes inziens is de interne accountant onafhankelijker in zijn doen en laten dan sommigen wel willen doen geloven. De interne accountant is bovendien in het voordeel ten opzichte van de externe accountant door zijn permanente aanwezigheid in de huishouding waardoor de interne accountant beter op de hoogte is met de dagelijkse gang van zaken dan de externe accountant.

Anderzijds kan niet worden ontkend dat een externe accountant onafhankelijker ten opzichte van de leiding staat dan een interne accountant.

Daarom kan worden gesteld dat, hoewel de interne accountant een rol van betekenis kan spelen bij het op het spoor komen van management-fraude, dit toch een specifiek terrein blijft voor de externe accountant. 
Terzijde zij voor wat betreft de positie van de interne accountant nog het volgende opgemerkt. Wanneer het vermoeden van fraude is gerezen zal een fraude-onderzoek worden ingesteld met als doel de aard en de omvang van de fraude vast te stellen. De strekking van dit fraude-onderzoek valt buiten het bestek van dit artikel.

Indien het echter een management-fraude betreft moet op grond van het voorgaande worden gesteld, dat dit onderzoek niet door de interne accountant dient te worden uitgevoerd, juist vanwege zijn plaats in de organisatie. Een dergelijk onderzoek ligt veeleer op het werkterrein van een externe accountant vanwege zijn onafhankelijker positie.

\subsection{Letter of Representation}

In het voorgaande is reeds gesteld dat, hoewel de accountant een zekere (mede-)verantwoordelijkheid draagt voor fraude, de primaire verantwoordelijkheid berust bij de leiding van de huishouding.

In Meningsuiting nummer $3^{7}$ wordt voorgesteld, de verantwoordelijke leiding een schriftelijke bevestiging bij de jaarrekening te laten ondertekenen. Dit stuk wordt in de literatuur wel aangeduid met de term 'letter of representation'. Door middel van dit stuk wordt nog eens nadruk gelegd op de primaire verantwoordelijkheid van de ondertekenende leiding voor de inhoud van de jaarrekening. Deze verantwoordelijkheid omvat tevens die voor fraudes. Derhalve verdient het onzes inziens, ook in verband met het hier behandelde onderwerp, aanbeveling dat de leiding in elk geval een dergelijk stuk ondertekent indien de accountant een verklaring bij de jaarrekening afgeeft.

Gebleken is, dat hierover in het maatschappelijk verkeer geen consensus bestaat. Voor een discussie over het aspect aansprakelijkheid moge worden verwezen naar het maandblad De Naamlooze Vennootschap ${ }^{5}$.

\subsection{Cohen - report}

In 1978 is van de Commission on Auditors' Responsibilities (de zogenaamde commissie Cohen) ${ }^{1}$ een rapport verschenen. Van de daarin vermelde conclusies en aanbevelingen zijn er in dit kader 2 van belang.

In de voorgaande paragraaf is de letter of representation aan de orde geweest. Door de commissie wordt nu voorgesteld deze letter of representation op te nemen in het directieverslag.

In paragraaf 2.2 is gesteld dat de primaire verantwoordelijkheid voor een goed opgezette en goed functionerende organisatie bij de leiding van de huishouding berust. Ten aanzien van dit aspect wordt door de commissie voorgesteld, dat de leiding in het jaarverslag een oordeel geeft over de kwaliteit van de interne controle en voorts dat de accountant meedeelt of hij zich al dan niet met deze visie kan verenigen.

Aan deze voorstellen zijn enige voordelen te onderkennen. Op deze wijze worden de genoemde verantwoordelijkheden daar gelegd waar zij horen. Vooral bij bedrijven waar een goede interne controle een levensvoorwaarde is (bijvoorbeeld verzekeringsmaatschappijen) kan dergelijke informatie van belang zijn. Deze voorstellen lijken dan ook het voordeel te hebben, dat 
meer duidelijkheid wordt verschaft ten opzichte van het maatschappelijk verkeer.

Bij nadere beschouwing rijst echter de vraag of deze werkwijze inderdaad nu wel zo duidelijk is. Op deze wijze wordt slechts gerapporteerd over een onderdeel van het totale beleid. Zelfs voor wat de organisatorische aspecten van de huishouding betreft wordt slechts een oordeel over een onderdeel gegeven. Zo wordt bijvoorbeeld geen voorstel gedaan een oordeel te geven over de kwaliteit van het management.

Limperg ${ }^{10}$ heeft er destijds op gewezen, dat de verklaring enerzijds duidelijk dient te zijn, maar anderzijds stelde hij de eis van volkomenheid en beknoptheid. Deze eisen gelden in deze tijd nog steeds.

Het is aan de accountant als deskundige overgelaten om vast te stellen hoe een onderzoek technisch dient te worden verricht; de lezer van de verklaring zal ervan uit kunnen gaan, dat het onderzoek op vaktechnisch verantwoorde wijze is verricht en is voltooid vóór de verklaring is afgegeven.

In paragraaf 2.1 is reeds vastgesteld dat deze lezer veelal zal moeten worden gezocht in de goed geïnformeerde bovenlaag van het maatschappelijk verkeer. Deze lezer mag er van uitgaan dat de accountant, teneinde tot zijn verklaring te komen, alles heeft gedaan wat noodzakelijk was. In de huidige beroepsopvattingen zal dat een evaluatie betekenen van de opzet en de werking van de interne controle.

Zie in dit verband de in paragraaf 2.2 besproken opvattingen van Frielink. Mede in het licht van Meningsuiting nummer $3^{7}$ zal de accountant tevens het middel van de letter of representation hanteren.

Mijns inziens is dit voor de goed geïnformeerde bovenlaag zo evident, dat dit geen nadere toelichting behoeft in de jaarrekening.

Indien het beroep bemerkt dat hierover onduidelijkheid bestaat, dient hierover duidelijkheid te worden verschaft aan het relevante deel van het maatschappelijk verkeer.

\section{Hoofdstuk 4: Conclusies}

1. In het maatschappelijk verkeer kan een zekere gelaagdheid worden onderkend. De door Limperg geïntroduceerde vertrouwensrelatie zal doorgaans slechts bestaan met de bovenlaag van informerende, toezichthoudende, belangenbehartigende of zelfs vertegenwoordigende instellingen.

2. Indien dit deel van het maatschappelijk verkeer meent, dat het belangrijkste doel van de accountantscontrole het aan het licht brengen van fraudes is, is er onzes inziens sprake van irrationele verwachtingen welke voortkomen uit een verkeerd begrip van de werkzaamheden van de accountant. In dat geval dient het beroep als geheel hierover duidelijkheid te verschaffen.

3. Indien het maatschappelijk verkeer (en de leiding van de gecontroleerde huishouding) verwachten dat de accountant bij de controle van de jaarrekening zwakke punten in de organisatie signaleert, betreft het rationele verwachtingen, die in de hiervoor beschreven driehoeksverhouding de relatie accountant-fraude bepalen. 
Deze relatie wordt wel aangeduid als de verantwoordelijkheid ex ante.

4. Indien een controle uitmondt in een goedkeurende verklaring bij de jaarrekening dient de accountant zich te realiseren dat hij een uitspraak doet over het beeld en dat hij, naast de leiding, mede verantwoordelijkheid draagt voor fraudes die dat beeld beïnvloeden.

Een uitzondering hierop kan gelden voor bepaalde fraudes, waarbij middels samenspanning, mits met de nodige perfectie opgezet en uitgevoerd, het systeem van interne controle is doorbroken. Hiervoor zou dan een axiomatisch voorbehoud gelden.

De hier geschetste relatie wordt wel aangeduid als de verantwoordelijkheid ex post.

5. Management-fraude kan zowel bestaan uit het onttrekken van waarden aan de huishouding als uit het geven van een valse voorstelling van zaken.

6. Voor managementsfraudes welke bestaan uit het geven van een valse voorstelling van zaken, zodanig dat het beeld van de jaarrekening wordt beïnvloed, is de accountant die een goedkeurende verklaring heeft afgegeven, meestal (mede-)verantwoordelijk.

7. Voor de vormen van management-fraude, die samenhangen met een geringe onderlinge controle binnen de leiding dan wel een doorbreking van het systeem van interne controle door de leiding, geldt ten aanzien van de (mede-)verantwoordelijkheid van de accountant het axiomatisch voorbehoud, mits de controle volgens de huidige beroepsopvattingen goed is opgezet en uitgevoerd.

8. Indien naast de externe accountant tevens een interne accountant is betrokken bij de controle van de jaarrekening, behoort het afwerken van een ontdekte management-fraude veeleer tot de taak van de externe dan van de interne accountant.

9. Indien bij de jaarrekening een verklaring wordt afgegeven, dient de accountant door de ondernemingsleiding een letter of representation te laten ondertekenen.

Het opnemen hiervan in het directieverslag schept geen grotere duidelijkheid, net zo min als het opnemen van een mededeling over de kwaliteit van de interne controle.

\section{Geraadpleegde literatuur}

1. Report, The Commission on Auditor's Responsibilities Conclusions and Recommandations,

An independant commission established by the American Institute of Certified Public Accountants, 1978.

2. Drs. W. J. van der Hooft, Maatschappelijk verkeren,

Accoord: afscheidsbundel Prof. drs. A. A. de Jong,

Erasmus Universiteit Rotterdam, 1976.

3. Prof. A. J. van 't Klooster en Drs. J. A. M. Oonincx,

Fraude en computer; Handboek Accountancy IV, 151.

4. Limperg Instituut, Amsterdam, Fraude, automatisering en accountant; diverse auteurs.

5. De Naamlooze Vennootschap, edities van oktober 1981 en februari 1982. 
6. A. Niekamp,

De accountant en fraude; Handboek Accountancy III, 71.

7. Nivra: Meningsuiting nummer 3.

8. Nivra: Ontwerp ter discussie nummer 1.

9. Drs. J. J. P. M. van Schie,

Management-fraude en de accountant,

Accoord: afscheidsbundel Prof. drs. A. A. de Jong,

Erasmus Universiteit Rotterdam, 1976.

10. J. M. Vecht,

De accountantsverklaring; Handboek Accountancy I, 50. 